\title{
A novel pancoronavirus RT-PCR assay: frequent detection of human coronavirus NL63 in children hospitalized with respiratory tract infections in Belgium
} Elien Moës ${ }^{1}$, Leen Vijgen ${ }^{1}$, Els Keyaerts ${ }^{1}$, Kalina Zlateva1 ${ }^{1}$ Sandra Li1 ${ }^{1}$, Piet Maes ${ }^{1}$, Krzysztof Pyrc ${ }^{2}$, Ben Berkhout ${ }^{2}$, Lia van der Hoek ${ }^{2}$ and Marc Van Ranst*1

Address: ${ }^{1}$ Laboratory of Clinical \& Epidemiological Virology, Department of Microbiology \& Immunology, Rega Institute for Medical Research, University of Leuven, Belgium and 2Department of Human Retrovirology, Academic Medical Center, University of Amsterdam, The Netherlands

Email: Elien Moës - elien.moes@uz.kuleuven.ac.be; Leen Vijgen - leen.vijgen@uz.kuleuven.ac.be; Els Keyaerts - els.keyaerts@uz.kuleuven.ac.be; Kalina Zlateva - kalina.zlateva@uz.kuleuven.ac.be; Sandra Li - sandra.li@uz.kuleuven.ac.be; Piet Maes - piet.3.maes@uz.kuleuven.ac.be; Krzysztof Pyrc - k.a.pyrc@amc.uva.nl; Ben Berkhout - b.berkhout@amc.uva.nl; Lia van der Hoek - c.m.vanderhoek@amc.uva.nl; Marc Van Ranst* - marc.vanranst@uz.kuleuven.ac.be

* Corresponding author

Published: 0I February 2005

BMC Infectious Diseases 2005, 5:6 doi:10.1 186/147/-2334-5-6

This article is available from: http://www.biomedcentral.com/147I-2334/5/6

(c) 2005 Moës et al; licensee BioMed Central Ltd.

This is an Open Access article distributed under the terms of the Creative Commons Attribution License (http://creativecommons.org/licenses/by/2.0), which permits unrestricted use, distribution, and reproduction in any medium, provided the original work is properly cited.
Received: 13 October 2004

Accepted: 0 I February 2005

\begin{abstract}
Background: Four human coronaviruses are currently known to infect the respiratory tract: human coronaviruses OC43 (HCoV-OC43) and 229E (HCoV-229E), SARS associated coronavirus (SARS-CoV) and the recently identified human coronavirus NL63 (HCoV-NL63). In this study we explored the incidence of HCoV-NL63 infection in children diagnosed with respiratory tract infections in Belgium.
\end{abstract}

Methods: Samples from children hospitalized with respiratory diseases during the winter seasons of 2003 and 2004 were evaluated for the presence of HCoV-NL63 using a optimized pancoronavirus RT-PCR assay.

Results: Seven HCoV-NL63 positive samples were identified, six were collected during January/ February 2003 and one at the end of February 2004.

Conclusions: Our results support the notation that HCoV-NL63 can cause serious respiratory symptoms in children. Sequence analysis of the $\mathrm{S}$ gene showed that our isolates could be classified into two subtypes corresponding to the two prototype HCoV-NL63 sequences isolated in The Netherlands in 1988 and 2003, indicating that these two subtypes may currently be cocirculating.

\section{Background}

Coronaviruses are large, enveloped, positive stranded RNA-viruses [1]. The viral RNA genome is $27-32 \mathrm{~kb}$ in size, capped, polyadenylated and encapsidated in a helical nucleocapsid. The envelope is studded with long, petal- shaped spikes, giving the virus particle a characteristic crown-like appearance. Three distinct groups of coronaviruses have been described based on serological affinity and genome sequence. Coronaviruses can infect humans and a variety of domestic animals and can cause highly 
prevalent diseases such as respiratory, enteric, cardiovascular and neurologic disorders $[2,3]$.

Until recently only three human coronaviruses were thoroughly studied. Human coronavirus OC43 (HCoV-OC43; group 2) and human coronavirus 229E (HCoV-229E; group 1) were identified in the 1960s. They are responsible for $10-30 \%$ of all common colds, and infections occur mainly during winter and early spring [4-7]. A third novel human coronavirus, SARS-CoV, was identified as the causal agent during the 2002-2003 outbreak of severe acute respiratory syndrome (SARS) [8-10]. Phylogenetic analysis showed that the SARS-CoV does not closely resemble any of the three previously known groups of coronaviruses, and therefore a tentative fourth group of coronaviruses was suggested $[11,12]$. However, an early split-off of the SARS-CoV from the coronavirus group 2 lineage has also been suggested $[13,14]$.

A new human coronavirus associated with respiratory illness, HCoV-NL63, was recently identified by a research team in The Netherlands [15]. The virus was isolated in January 2003 from a nasopharyngeal aspirate of a 7month-old child suffering from bronchiolitis, conjunctivitis and fever. Screening of specimens from patients with respiratory symptoms identified seven additional $\mathrm{HCoV}$ NL63 infected individuals, both children and adults, between December 2002 and February 2003. The complete viral genome sequence was determined. The characteristic genome organisation of coronaviruses can be observed: the $5^{\prime}$ two-third of the genome contains two large open reading frames (ORF), ORF1a and ORF1b. In the 3' part of the genome, genes encoding four structural proteins are found: spike (S), envelope (E), membrane $(\mathrm{M})$, and nucleocapsid $(\mathrm{N})$. The hemagglutinin-esterase (HE) gene, characteristic for group 2 coronaviruses, is not present in HCoV-NL63. Sequence analysis demonstrated that HCoV-NL63 shares $65 \%$ sequence identity with $\mathrm{HCoV}-229 \mathrm{E}$. Phylogenetic analysis confirmed that HCoVNL63 is a new group 1 coronavirus, most closely related to $\mathrm{HCoV}-229 \mathrm{E}$ and porcine epidemic diarrhea virus (PEDV) [15]. Shortly after van der Hoek and colleagues published their discovery of the new human coronavirus HCoV-NL63, a second research group described the characterization of essentially the same virus [16]. The virus was isolated from a nose swab sample collected from an 8-month-old child suffering from pneumonia in The Netherlands in April 1988. Real-time RT-PCR assays were designed for screening of respiratory tract samples. Four additional HCoV-NL63 positive samples, from children aged 3 months to 10 years, were detected between November 2000 and January 2001.

HCoV-NL63 can be considered as a new important cause of respiratory illnesses and two different subtypes might be currently cocirculating in the human population [15]. In this study we wanted to explore the incidence of $\mathrm{HCoV}$ NL63 infection in children diagnosed with respiratory tract infections in Belgium.

\section{Methods \\ Isolates and patients}

We studied 309 isolates from 279 patients with severe respiratory symptoms collected from January 2003 until March 2004 at the University Hospital in Leuven, Belgium. These isolates originated from bronchoalveolar lavages, pharyngeal swabs, nasopharyngeal aspirates, and sputum samples. Routine diagnostic testing was performed for respiratory syncytial virus (RSV), influenza virus, parainfluenza virus and adenovirus. No prior amplification by cell culture was performed. The results of diagnostic tests for RSV were negative for 244 isolates, while 65 isolates were positive for RSV. Patients ranged in age from 1 month to 16 years, with a mean age of 2 years. The temporal distribution of the isolates corresponded to the yearly RSV epidemic period: 236 samples were collected from January to June 2003 and 73 samples were recovered during the first trimester of 2004 (Figure 1A).

\section{Pancoronavirus RT-PCR assay}

RNA was extracted from the collected specimens by using the QIAamp Viral RNA Mini kit (QIAGEN, Westburg, The Netherlands) according to instructions of the manufacturer. Screening of the samples was performed by amplifying a $251 \mathrm{bp}$ fragment of the polymerase gene using the following primer set: Cor-FW (5'-ACWCARHTVAAYYTNAARTAYGC-3') and Cor-RV (5'-TCRCAYTTDGGRTARTCCCA-3') (Figure 2). These one-step RT-PCR assays (OneStep RT-PCR kit; QIAGEN) were undertaken in a $50 \mu \mathrm{l}$ reaction volume containing $10 \mu \mathrm{L}$ RNA-extract, $10 \mu \mathrm{l}$ 5x QIAGEN OneStep RT-PCR Buffer, $2 \mu \mathrm{l}$ dNTP mix (final concentration of $400 \mu \mathrm{M}$ of each dNTP), $1.8 \mu \mathrm{l}$ QIAGEN OneStep RT-PCR Enzyme Mix (a combination of Omniscript and Sensiscript reverse transcriptase and HotStarTaq DNA polymerase), $4 \mu \mathrm{M}$ of each primer, and RNase-free water to $50 \mu \mathrm{l}$. The reaction was carried out with an initial reverse transcription step at $50^{\circ} \mathrm{C}$ for 30 min, followed by PCR activation at $95^{\circ} \mathrm{C}$ for $15 \mathrm{~min}, 50$ cycles of amplification (30 sec at $94^{\circ} \mathrm{C} ; 30 \mathrm{sec}$ at $48^{\circ} \mathrm{C} ; 1$ min at $72^{\circ} \mathrm{C}$ ), and a final extension step at $72^{\circ} \mathrm{C}$ for 10 min in a GeneAmp PCR system 9600 thermal cycler (Applied Biosystems, Foster City, CA, USA). PCR-products were run on a polyacrylamide gel, stained with ethidium bromide, and visualized under UV-light.

\section{RT-PCR assays for HCoV-NL63}

Samples that were found positive for HCoV-NL63 were confirmed using one-step RT-PCR assays, which amplified four different regions of the HCoV-NL63 genome. Amplification of a 314-bp gene fragment in the nucleocapsid 
A

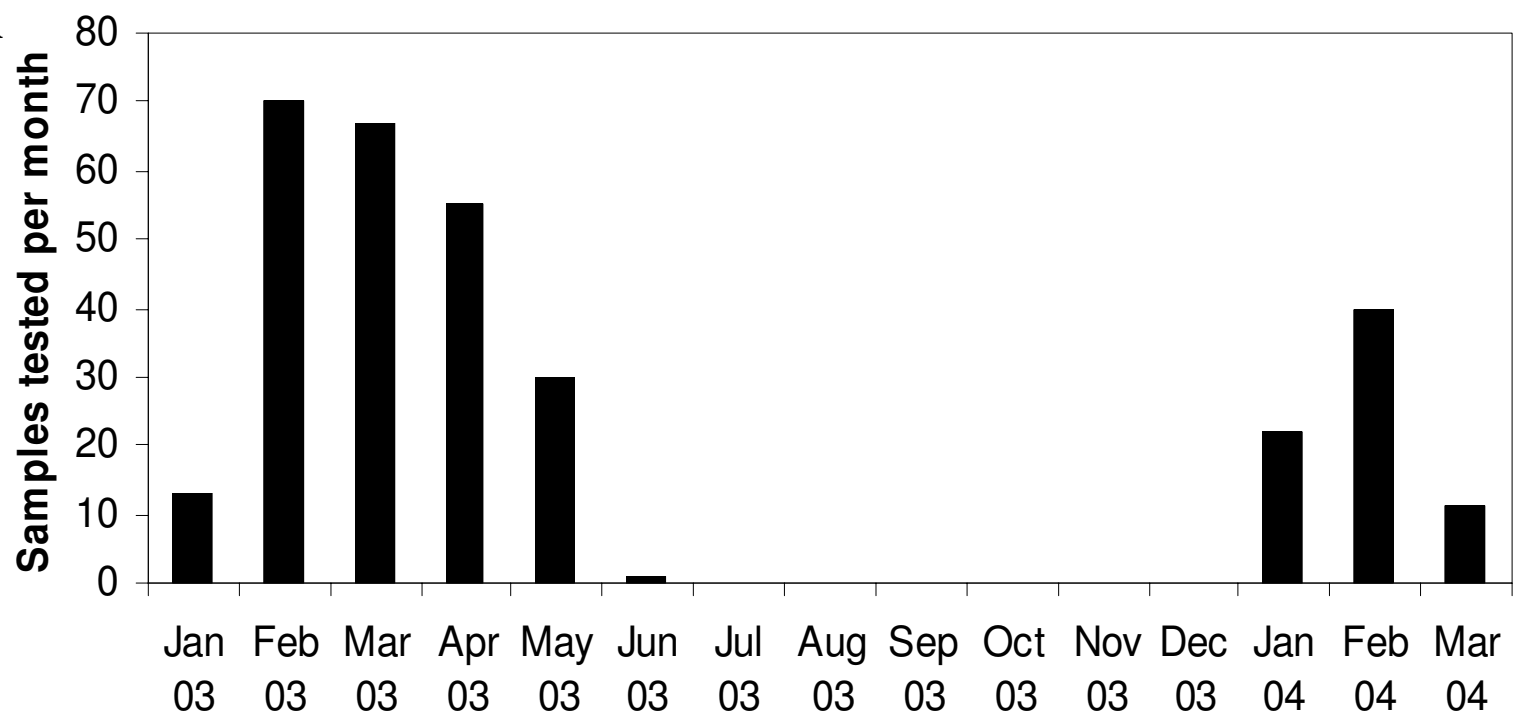

B

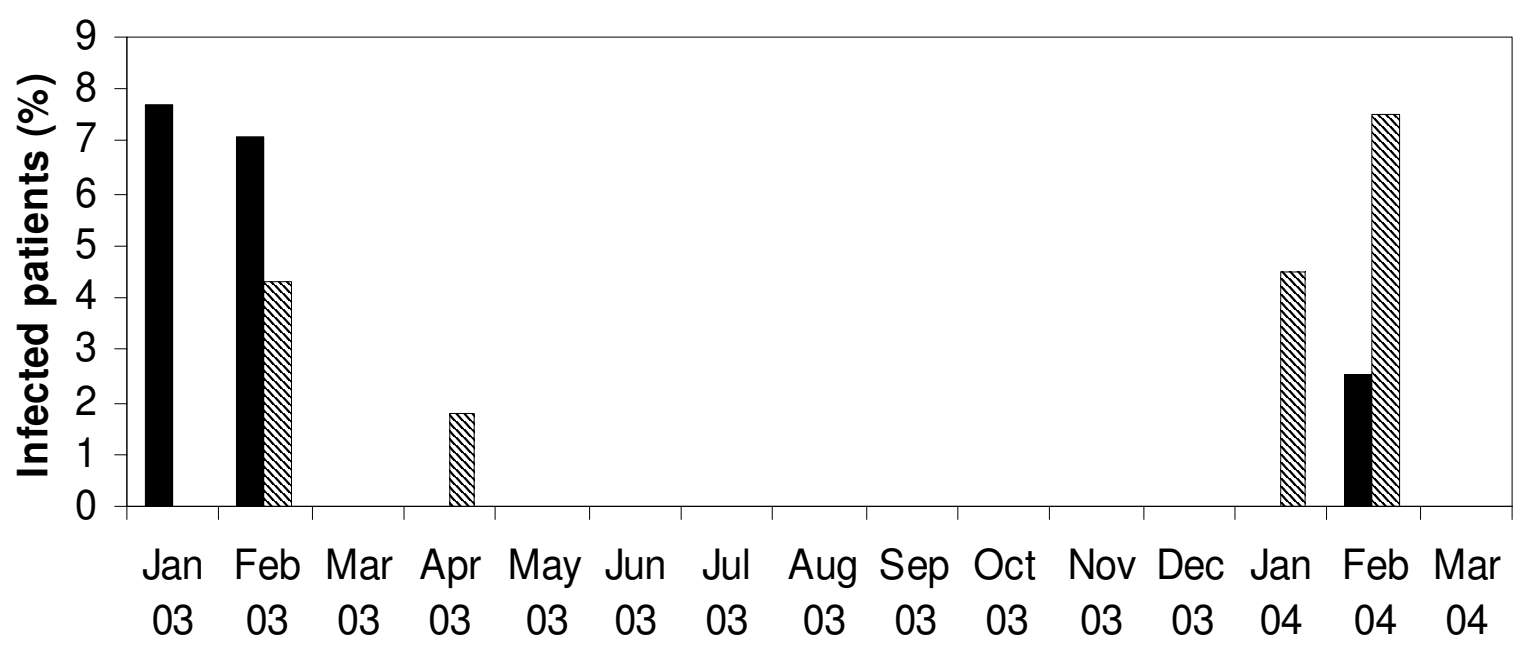

HCoV-NL63 infected patients $\mathbb{H C O V - O C 4 3 ~ i n f e c t e d ~ p a t i e n t s ~}$

Figure I

Detection of HCoV-NL63 and HCoV-OC43 in samples from patients suffering from severe respiratory symptoms. (A)

Number of samples tested per month. (B) Patients infected with HCoV-NL63 and HCoV-OC43. A single HCoV-229E positive sample was isolated in April 2003 (not shown).

region was performed with two specific HCoV-NL63 primers: N5-PCR1 (5'-CTGTTACTTTGGCTTTAAAGAACTTAGG-3', nt 26695-nt 26721) and N3-PCR1 (5'-CTCACTATCAAAGAATAACGCAGCCTG-3', nt 26982-nt 27008). Secondly a 237-bp fragment in ORF1b was amplified using the primers repSZ-1 and repSZ-3 described by van der Hoek and colleagues [15]. A third RT-PCR assay was carried out on the HCoV-NL63 positive samples amplifying a 839-bp fragment with ORF1a specific primers: SS5852-5P and P4G1M-5-3P [15]. These one-step RT-PCR 
Forward primer region

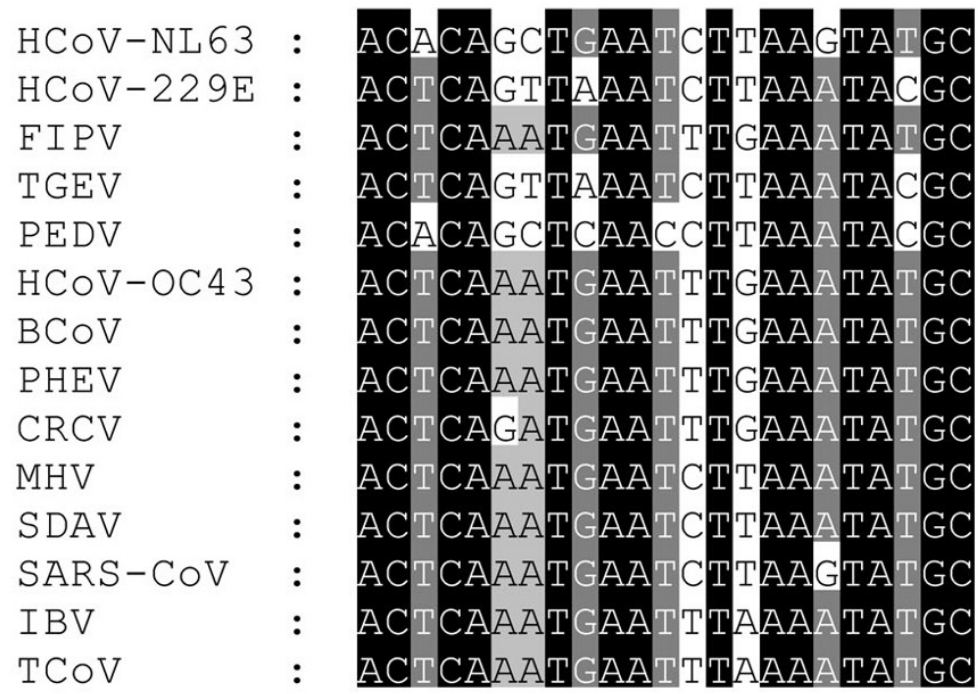

ACWCARHTVAAYYTNAARTAYGC
Reverse primer region

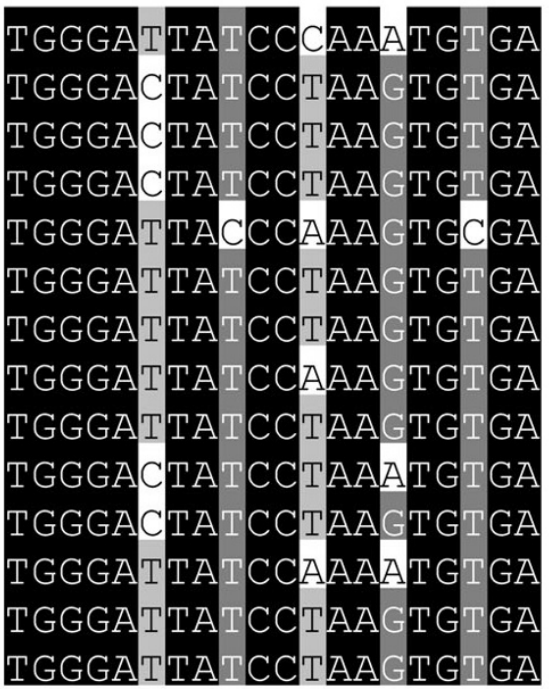

TGGGAYTAYCCHAARTGYGA

\section{Figure 2}

Selection of primers for the novel pancoronavirus RT-PCR. Shown is the alignment of I 4 coronaviral sequences of a conserved region of the polymerase gene. The forward (Cor-FW) and reverse (Cor-RV) primer sequences are shown at the bottom $(\mathrm{Y}=$ $\mathrm{C} / \mathrm{T}, \mathrm{W}=\mathrm{A} / \mathrm{T}, \mathrm{V}=\mathrm{A} / \mathrm{C} / \mathrm{G}, \mathrm{R}=\mathrm{A} / \mathrm{G}, \mathrm{H}=\mathrm{A} / \mathrm{T} / \mathrm{C}, \mathrm{N}=\mathrm{A} / \mathrm{C} / \mathrm{T} / \mathrm{G})$. The coordinates of Cor-FW and Cor-RV are 14017 and 14248, respectively, in the HCoV-NL63 complete genome sequence. The 14 coronavirus sequences used here are available from GenBank under the following accession numbers: HCoV-NL63, AY567487; HCoV-229E, AF304460; infectious bronchitis virus (IBV), Z3054I; SARS-CoV, AY3 I3906; HCoV-OC43, AY39I777; PEDV, AF3535I I; bovine coronavirus (BCoV),

AF39I 54I; transmissible gastroenteritis virus, AF304460; MHV, X51939; PHEV, AFI 24988; sialodacryoadenitis virus (SDAV), AFI 24990; turkey coronavirus (TCoV), AFI 2499I; canine respiratory coronavirus (CRCV), AYI50273; feline infectious peritonitis virus (FIPV), AFI24987.

assays were performed essentially as described above. They were carried out using $5 \mu \mathrm{L}$ RNA-extract and $0.6 \mu \mathrm{M}$ of each primer. Only 45 cycles of amplification were run and annealing temperature was set at $50^{\circ} \mathrm{C}$. Furthermore a $663 \mathrm{bp}$ fragment of the spike gene was amplified using a RT-nested PCR. The outer primer set SINL5 (5'-GAGTTTGATTAAGAGTGGTAGGTTG-3', nt 20391-nt 20415) and SINL3 (5'-AACAGTGTAGTTAACTACACGG-3', nt 21068nt 21089) were used in a one-step RT-PCR, performed as described above, using $10 \mu \mathrm{l}$ of RNA-extract and an annealing temperature of $48^{\circ} \mathrm{C}$. A nested PCR was carried out with the inner primer set SINL5n (5'-GGTTGTTGTTACGCAATAATGGTCGT-3', nt 20411-nt 20436) and SINL3n (5'-ACACGGCCATTATGTGTGGTGAC-3', nt 21051-nt 21073). The nested reaction mix was composed of 1 unit Taq polymerase, $1 \mu \mathrm{l}$ of a $25 \mathrm{mM}$ dNTP-mix, 10 $\mu \mathrm{l} 5 \mathrm{X}$ buffer C (PCR Optimizer Kit, Invitrogen, The Neth- erlands), and $30 \mathrm{pmol}$ of forward and reverse primer in a $50 \mu \mathrm{l}$ reaction volume. As template $10 \mu \mathrm{l}$ of the outer PCR product was added. The cycling conditions were as follows: an initial denaturation at $94^{\circ} \mathrm{C}$ for $5 \mathrm{~min}$, followed by 40 cycles of amplification ( $45 \mathrm{sec}$ at $94^{\circ} \mathrm{C}, 45 \mathrm{sec}$ at $54^{\circ} \mathrm{C}, 1 \mathrm{~min}$ at $72^{\circ} \mathrm{C}$ ), and a final extension of $5 \mathrm{~min}$ at $72^{\circ} \mathrm{C}$. PCR-products were run on a polyacrylamide gel, stained with ethidium bromide, and visualized under UVlight. The amplicons were purified using the QIAquick PCR purification kit (QIAGEN) and sequenced with the respective primer pairs using the ABI PRISM BigDye Terminator Cycle Sequencing Reaction kit (version 3.1) on an ABI PRISM 3100 DNA sequencer (Applied Biosystems) according to the manufacturer's instructions. Positive and negative controls were included in each PCR experiment. The HCoV-NL63 positive control was RNA isolated from a HCoV-NL63 culture. 


\section{Sequence analysis and phylogenetic analysis of the amplicons}

Chromatogram sequencing files were inspected with Chromas 2.2 (Technelysium Pty Ltd, Helensvale, Australia), and contigs were prepared using SeqMan II (DNASTAR, Madison, WI, USA). The obtained consensus sequences were compared with the prototype HCoVNL63 sequences available in GenBank database release 142.0 using BLAST analysis (NCBI BLAST server). Multiple sequence alignments were prepared using CLUSTAL X version 1.82 [26], and manually edited in the GeneDoc Alignment editor [27]. Phylogenetic analysis was conducted using MEGA version 2.1 [28].

\section{Nucleotide sequence accession numbers}

The sequences determined in this study have been deposited in the GenBank sequence database under accession numbers AY758276 to AY758301.

\section{RT-PCR assays for HCoV-OC43 and HCoV-229E}

Our collection of samples was also screened using the pancoronavirus RT-PCR assay for the presence of $\mathrm{HCoV}$ OC43 and HCoV-229E. Positive results were confirmed by one-step RT-PCR using HCoV-OC43 and HCoV-229E specific primer pairs located in the membrane glycoprotein region (OC43-FW: 5'-GGCTTATGTGGCCCCTTACT3', nt 28580-nt 28599; OC43-RV: 5'-GGCAAATCTGCCCAAGAATA-3', nt 28894-nt 28913; 229E-FW: 5'TGGCCCCATTAAAAATGTGT-3', nt 24902-nt 24921; 229E-RV: 5'-CCTGAACACCTGAAGCAAT-3', nt 25456-nt 25475) [18]. One-step RT-PCR and sequence analysis were performed essentially as described above. Annealing conditions during the RT-PCR assay were modified: the annealing temperature was set at $55^{\circ} \mathrm{C}$.

\section{Results}

\section{Pancoronavirus RT-PCR assay}

A pancoronavirus RT-PCR assay is a usefull tool to test for all coronaviruses in a clinical sample. Besides quick screening for several pathogens in one assay, it supplies the possibility to identify previously unknown coronaviruses. The consensus RT-PCR assay as described by Stephensen et al., designed to amplify all known coronaviruses, is not able to detect HCoV-NL63 because of several mismatches with the primer sequences $[15,17]$. We modified these consensus primers based on an alignment of the HCoV-NL63 prototype sequence and 13 other coronavirus sequences (Figure 2). To determine whether the newly designed pancoronavirus RT-PCR assay efficiently amplifies a broad range of coronaviruses the RTPCR assay was tested on cell culture supernatant of the four known human coronaviruses and three animal coronaviruses: HCoV-NL63, HCoV-OC43, HCoV-229E, SARS$\mathrm{CoV}$, feline infectious peritonitis virus (FIPV), porcine hemagglutinating encephalomyelitis virus (PHEV), and murine hepatitis virus (MHV). Amplification of the expected 251 bp region was observed for all tested coronaviruses (Figure 3). The sensitivity of the pancoronavirus RT-PCR assay was assessed by testing tenfold dilutions of HCoV-NL63 and HCoV-OC43 RNA. While 50 copies of $\mathrm{HCoV}-\mathrm{OC} 43 \mathrm{RNA}$ copies per $\mu \mathrm{l}$ nasopharyngeal aspirate could be detected, the sensitivity for HCoV-NL63 was a bit lower i.e. $5 \times 10^{3}$ RNA copies per $\mu$ nasopharyngeal aspirate.

\section{Detection of HCoV-NL63 in clinical specimens}

The pancoronavirus RT-PCR assay was used for screening of specimens from hospitalized patients with respiratory symptoms collected between January 2003 and March 2004. Samples, from which a 251 bp fragment could be amplified, were further identified by sequencing using the pancoronavirus primers. We studied 309 specimens with a temporal distribution that corresponded with the yearly RSV epidemic period (Figure 1A). A total of 244 samples were found negative for RSV by diagnostic testing. The 279 patients in this study comprised of 211 patients aged $<2$ years $(75.6 \%), 68$ aged $2-16$ years $(24.4 \%)$. We detected HCoV-NL63 in 7 samples (2.3\%). One positive sample was collected at the end of January 2003 and coinfection with RSV type B was present. Five of the positive samples were collected within a ten-day period at the end of February 2003, and one positive sample was collected at the end of February 2004, which showed coinfection with adenovirus and parainfluenza virus (Figure 1B, Table 1 ). The seven positive samples were obtained from one patient aged 1 month, four patients of 1 year, one patient of 2 years, and one patient of 16 years. The patient files showed that all subjects suffered from respiratory tract illness and some had underlying disease (Table 1).

The seven HCoV-NL63 positive respiratory samples were confirmed by alternative RT-PCR assays. Amplification of a fragment of the nucleocapside gene and ORF1b was carried out. Sequence analysis of the $\mathrm{N}$ gene fragments and the ORF1b fragments showed $98-100 \%$ similarity to the prototype HCoV-NL63 sequences available in the GenBank database (AY567487, AY518894). A third one-step RT-PCR was carried out for each positive sample to amplify part of the ORF1a gene. Sequence analysis of the ORF1a PCR-products revealed 99\% sequence identity with both HCoV-NL63 prototype sequences available in GenBank. A neighbor-joining phylogenetic tree was constructed based on an alignment of the ORF1a nucleotide sequences from the HCoV-NL63 positive samples and the available HCoV-NL63 sequences in GenBank. HCoV-229E was used as an outgroup. The dendrogram shows that all HCoV-NL63 sequences cluster together, but two subclusters can be observed (Figure 4). 


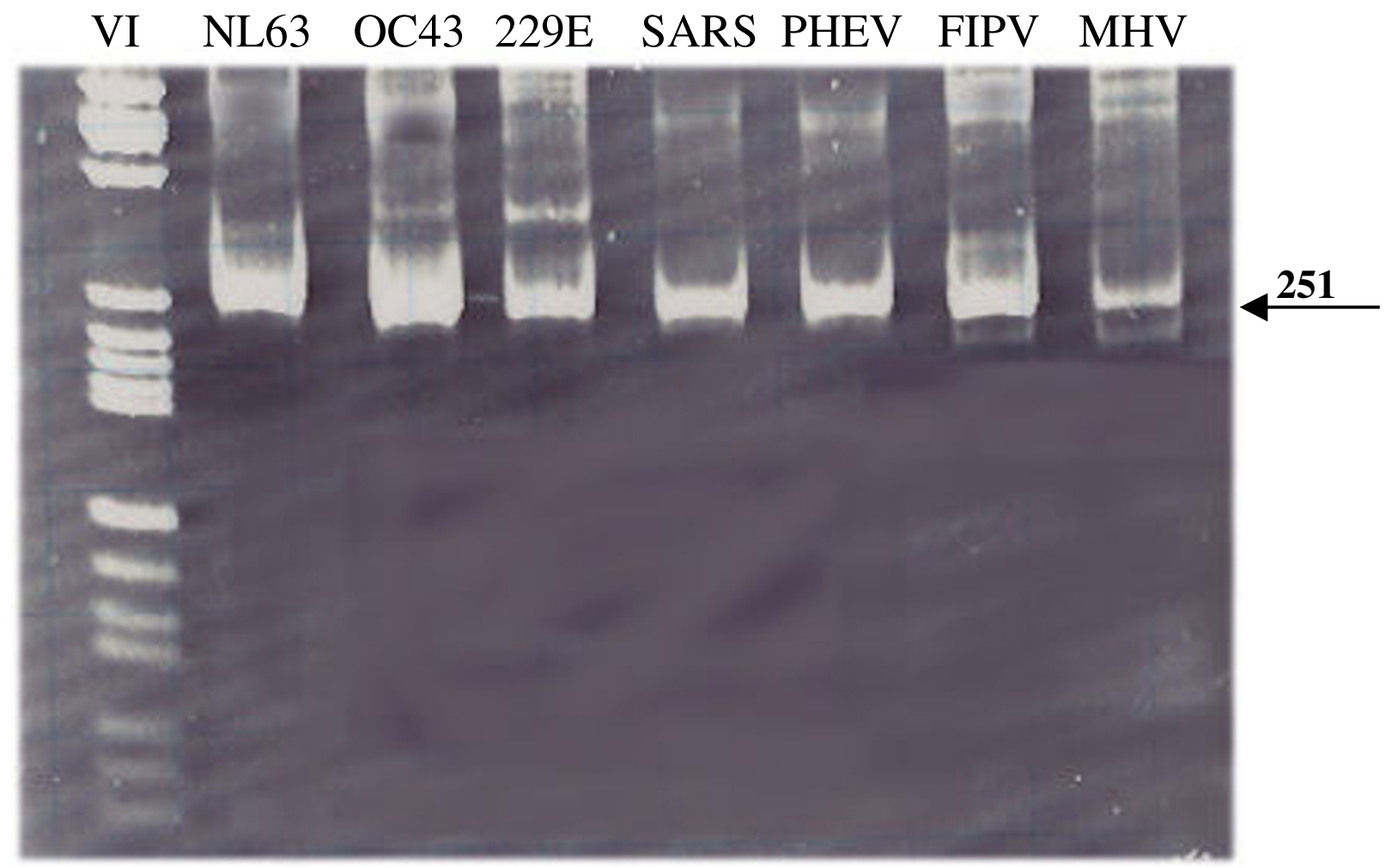

\section{Figure 3}

Gel electrophoresis after pancoronavirus RT-PCR assay. The indicated band of $25 \mathrm{I}$ bp corresponds with the expected amplicon size. As a marker Molecular Weight Marker VI was used (Boehringer Mannheim, Germany).

Table I: Patients hospitalized with respiratory tract illness associated with HCoV-NL63 infection

\begin{tabular}{|c|c|c|c|c|c|c|}
\hline Patient nr. & Age & Sex & Symptoms & Underlying disease & Specimen & Sample date \\
\hline $1153^{a}$ & I year & male & URTI: fever, coughing, wheezing, rhinitis, diarrhoea & none & NPA & 27 Jan 2003 \\
\hline 33545 & 16 years & male & LRTI: fever, coughing, respiratory distress, pharyngitis & Smith-Lemli-Opitz syndrome & NPA & I4 Feb 2003 \\
\hline 21596 & I year & female & LRTI: fever, coughing, respiratory distress & Vater syndrome, epilepsy & NPA & 20 Feb 2003 \\
\hline 53887 & I month & female & URTI: fever, rhinitis, two siblings have URTI & none & NPA & 20 Feb 2003 \\
\hline 40001 & I year & male & $\begin{array}{l}\text { LRTI: respiratory distress, cardiac arrest, rotavirus- } \\
\text { positive diarrhoea }\end{array}$ & epilepsy & NPA & 2I Feb 2003 \\
\hline 64880 & 2 years & male & URTI: fever, coughing, wheezing & neurofibromatosis & NPA & 24 Feb 2003 \\
\hline $70688^{b}$ & I year & female & LRTI: pneumonia, fever, cyanosis, diarrhoea & none & PS & 25 Feb 2004 \\
\hline
\end{tabular}

apositive for RSV type B; bpositive for adenovirus and parainfluenza virus

LRTI, lower respiratory tract illness; URTI, upper respiratory tract illness; PS, pharyngeal swab; NPA, nasopharyngeal aspirate 


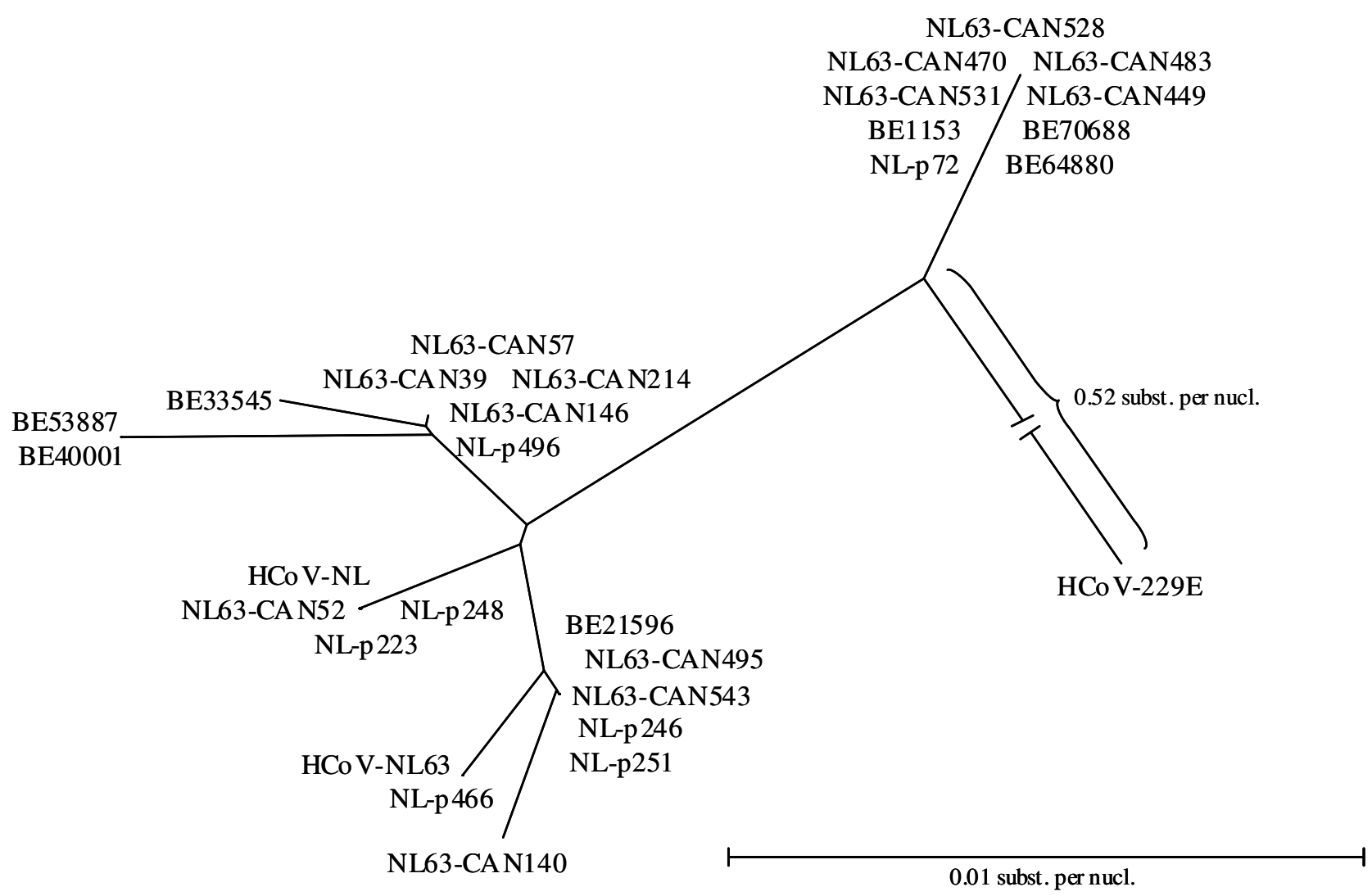

\section{Figure 4}

Phylogenetic analysis of the partial ORFIa nucleotide sequences. Accession numbers: HCoV-NL63, AY567487; HCoV-NL, AY5 I8894; HCoV-229E, AF304460; NL-p466, AY567488; NL-p246, AY567489; NL-p25I, AY567490; NL-p496, AY56749I; NL-p223; AY567492; NL-p248, AY567493; NL-p72, AY567494; CAN39, AY67554I; CAN52, AY675542; CAN57, AY675543; CANI40, AY675544; CANI46, AY675545; CAN2I4, AY675546; CAN449, AY675547; CAN470, AY675548; CAN483, AY675549; CAN495, AY675550; CAN528, AY67555I; CAN53I, AY675552; CAN543, AY675553.

Inspection of the two full genome HCoV-NL63 sequences available in GenBank demonstrates that especially the aminoterminal region of the Spike protein can be very divergent. Therefore we decided to amplify this region to investigate the variability of these region in our patients. An RT-nested PCR assay was used to amplify part of the S gene. These partial spike sequences showed 98\% similarity with the HCoV-NL63 prototype strains. An alignment of the $\mathrm{S}$ gene sequences from the Belgian samples, partial spike sequences from the positive samples identified in The Netherlands (data not shown), and the prototype HCoV-NL63 sequences, was used to constitute a neighbor-joining phylogenetic tree. The neighbor-joining tree was evaluated by 500 bootstrap pseudoreplicates. Two clusters can again be observed (Figure 5).

\section{Detection of HCoV-OC43 and HCoV-229E}

Screening of our sample collection for the presence of $\mathrm{HCoV}-\mathrm{OC} 43$ and HCoV-229E was also performed. We detected HCoV-OC43 in 7 of 309 samples $(2.3 \%)$ and $\mathrm{HCoV}-229 \mathrm{E}$ in one sample $(0.3 \%)$. The seven $\mathrm{HCoV}-$ OC43 positive samples were collected during the winter and early spring of 2003 and 2004. The sample in which we detected HCoV-229E was collected in April 2003. The positive samples were confirmed by RT-PCR using specific $\mathrm{HCoV}-\mathrm{OC} 43$ and HCoV-229E primer pairs that amplify part of the M gene [18]. The HCoV-OC43 and HCoV-229E 


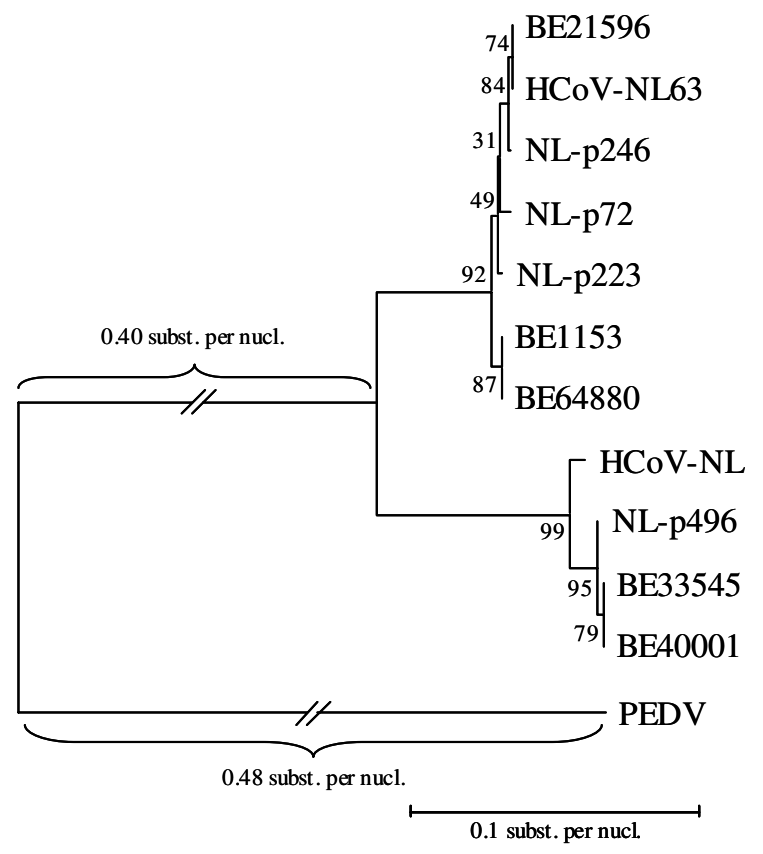

Figure 5

Phylogenetic analysis of the partial $\mathrm{S}$ gene nucleotide sequences based on an alignment of the Belgian spike sequences, spike sequences from the positive samples identified in The Netherlands, and the prototype HCoV-NL63 sequences available in GenBank. Accession numbers: $\mathrm{HCoV}$ NL63, AY567487; HCoV-NL, AY5 I8894. PEDV was used as an outgroup.

partial membrane sequences of the contemporary Belgian strains showed 97-99\% similarity with the HCoV-OC43 and HCoV-229E prototype sequences in GenBank.

\section{Discussion}

RSV, influenza viruses, adenoviruses, and parainfluenzaviruses are probably the most important viral agents of severe respiratory diseases. However, a substantial part of respiratory tract infections can not be attributed to any known pathogen. Underlying conditions and immunosuppression largely determine the impact of respiratory viruses on individuals [19]. The common cold viruses HCoV-OC43 and HCoV-229E have also been associated with more severe lower respiratory tract conditions in infants and immunocompromised patients [20-23]. The clinical symptoms associated with $\mathrm{HCoV}-\mathrm{NL} 63$ infections still need to be determined, but there are some indications that HCoV-NL63 can cause severe respiratory illnesses in children and immunocompromised adults $[15,16]$. We detected HCoV-NL63, using a pancoronavirus RT-PCR, in patients suffering from relatively severe respiratory dis- eases necessitating hospitalization. These positive samples were collected from children aged 1 month to 16 years. Two patients suffered from severe underlying disease: one patient suffered from Smith-Lemli-Opitz syndrome, a rare autosomal recessive disorder due to a primary enzymatic defect in the cholesterol metabolism. A second patient was diagnosed with VATER, a syndrome characterized by the sporadic association of specific birth defects or abnormalities such as vertebrae and vascular anomalies, anal atresia, trachea and esophagus problems and renal anomalities. All HCoV-NL63 infected patients established a complete recovery from their respiratory symptoms. One-step RT-PCR assays were used to detect and confirm these positive samples.

Results from epidemiological surveys conducted in the 1970 's have led to the conclusion that human coronaviruses are distributed worldwide and circulate during seasonal outbreaks [22]. Our results indicate that $\mathrm{HCoV}$ NL63 is the causal agent in a significant portion of respiratory diseases of unknown etiology. We detected $\mathrm{HCoV}$ NL63 in respiratory samples collected in February 2003, with a frequency of $7.1 \%$, and during February 2004, with a frequency of $2.5 \%$. These results seem to support the tendency of human coronaviruses to circulate mainly during the winter season $[7,24]$. However, in this study, sampling was only performed from January to May during the yearly RSV epidemic period, while no samples from the summer and autumn months were screened. The first publication on HCoV-NL63 showed that the virus circulated in Amsterdam during the winter months of 2002/ 2003 [15]. More recently another set of Amsterdam samples was screened, obtained during the winter of 2001/ 2002 and 2003/2004. HCoV-NL63 was found in one trachea sample obtained in February 2002, and in two oropharyngeal aspirates from December 2003 and January 2004, respectively (data not shown). Combined with the data that we present here from Belgium, these findings confirm that HCoV-NL63 reappears each winter season similar to the previously known respiratory viruses. Recently, research teams from Australia, Japan and Canada, have submitted partial HCoV-NL63 sequences to the GenBank database (AY600442-AY600446, AY662694AY662698, AY675541-AY675553). This indicates that this newly discovered human coronavirus has a worldwide distribution.

Sequence analysis of the highly conserved nucleocapsid region showed that the Belgian isolates are similar to the two prototype HCoV-NL63 complete genome sequences in GenBank isolated in the Netherlands in 1988 and 2003. Furthermore, phylogenetic analysis of part of the ORF 1a region of our patients showed the same subclusters of HCoV-NL63 that were described previously [15] (Figure 4). This finding supports the suggestion that 
several HCoV-NL63 subtypes with distinct molecular markers are cocirculating, also in Belgium. A large insert in the 5' part of the S gene of HCoV-NL63 compared with HCoV-229E has been described $[15,16]$. Both HCoVNL63 complete genome sequences show only $89 \%$ sequence identity in this spike insert region, which implies that there are at least two different HCoV-NL63 subtypes. Sequence analysis of this spike insert region revealed that our samples show similarity to both prototype HCoV-NL63 subtypes, which was confirmed by phylogenetic analysis. The partial $\mathrm{S}$ gene sequences cluster together with the two prototype $\mathrm{HCoV}-\mathrm{NL} 63$ sequences in two different groups (Figure 5). This confirms that the HCoV-NL63 subtypes first isolated in 1988 and 2003 are cocirculating. When analysing the dendrograms based on ORF1a and S gene sequences, a discordance in the clustering pattern of some $\mathrm{HCoV}-\mathrm{NL} 63$ isolates (e.g. HCoV-NL and NL-p223) can be observed, suggesting a possible recombination event. Further research of complete genome sequences of these isolates is required. Drawing conclusions based on phylogenetic analysis of one single gene therefore requires caution as the true phylogeny can only be demonstrated by analysing complete genome sequences.

Screening of our sample collection for the presence of $\mathrm{HCoV}-\mathrm{OC} 43$ and $\mathrm{HCoV}-229 \mathrm{E}$ revealed seven $\mathrm{HCoV}-$ OC43 positive samples and only one $\mathrm{HCoV}-229 \mathrm{E}$ positive sample. All positive samples were isolated during winter and early spring, which is concordant with the results of previous epidemiological studies. HCoV-OC43 infected samples were mainly identified during February 2003 and February 2004 (Figure 1B). These data show that the epidemic seasons of HCoV-OC43 and HCoV-NL63 coincide. The positive samples were collected from children aged 1 to 12 years, whom all suffered from respiratory symptoms. The very low detection rate of $\mathrm{HCoV}-229 \mathrm{E}$ compared with the frequent detection of HCoV-NL63, might imply that HCoV-NL63, closely related to HCoV-229E, is currently more important as a causal agent of respiratory diseases. At the moment, there are no data concerning cross-neutralization between $\mathrm{HCoV}-229 \mathrm{E}$ and $\mathrm{HCoV}-$ NL63. In theory, such cross-neutralization might be possible, since both viruses are relatively closely related species belonging to coronavirus group 1. Antigenic crossreactivity has already been demonstrated between SARS$\mathrm{CoV}$ and group 1 coronaviruses TGEV, FIPV and CCoV [25].

The development of a pancoronavirus RT-PCR assay using a primer set that matches all known coronaviruses might be useful for the identification of new coronaviruses. This pancoronavirus RT-PCR-assay can also be used as a diagnostic tool to detect any of the four currently known human coronaviruses in clinical samples.

\section{Conclusions}

Human coronavirus NL63 is a new important respiratory pathogen that can cause severe respiratory infections in children. Sequence analysis of the HCoV-NL63 isolates detected in our study demonstrates that our Belgian isolates can be classified into two subtypes corresponding to the two prototype HCoV-NL63 sequences isolated in The Netherlands in 1988 and 2003. Our findings indicate that these two subtypes may currently be cocirculating.

\section{Competing interests}

The author(s) declare that they have no competing interests.

\section{Author's contributions}

EM conceived of the study and designed it together with LV, EK, and MVR. EM developed the pancoronavirus RTPCR and performed the RT-PCR and sequencing reactions. EM and LV drafted the manuscript. KZ assembled the respiratory samples. SL performed the RT-PCR sensitivity assays. PM was responsible for the graphical support of the manuscript. LVDH, KP and BB developed the HCoV-NL63 RT-PCRs and helped with the design of the study and the writing of the manuscript. All authors contributed to the final version of the manuscript, read and approved it.

\section{Acknowledgements}

We would like to thank all the colleagues of the laboratory of Clinical \& Epidemiological Virology, Department of Microbiology \& Immunology, Rega Institute for Medical Research, University of Leuven, Belgium, and the Department of Retrovirology, Academic Medical Center, University of Amsterdam, The Netherlands, for helpful comments and discussion. This work was supported by a fellowship of the Flemish Fonds voor Wetenschappelijk Onderzoek (FWO) to Leen Vijgen, and by FWO-grant G.0288.0I.

\section{References}

I. Cavanagh D: Nidovirales: a new order comprising Coronaviridae and Arteriviridae. Arch Virol 1997, 142:629-633.

2. Lai MMC, Holmes KV: Coronaviridae: the viruses and their replication. In Fields Virology 4th edition. Edited by: Knipe DM, Howley PM. Lippincott Williams \& Wilkins; Philadelphia; 200 I: I I63-I I 85.

3. Guy JS, Breslin JJ, Breuhaus B, Vivrette S, Smith LG: Characterization of a coronavirus isolated from a diarrheic foal. I Clin Microbiol 2000, 38:4523-4526.

4. Tyrrell DAJ, Bynoe ML: Cultivation of novel type of commoncold virus in organ cultures. $\mathrm{Br}$ Med $\int 1965,5448$ : I 467-I470.

5. Hamre D, Procknow JJ: A new virus isolated from the human respiratory tract. Proc Soc Exp Biol Med 1966, 121:190-193.

6. Almeida JD, Tyrrell DA: The morphology of three previously uncharacterized human respiratory viruses that grow in organ culture. J Gen Virol 1967, 1: 175-178.

7. Larson HE, Reed SE, Tyrell DAJ: Isolation of rhinoviruses and coronaviruses from 38 colds in adults. J Med Virol 1980, 5:221-229.

8. Drosten C, Gunther S, Preiser W, van der Werf S, Brodt HR, Becker S, Rabenau H, Panning M, Kolesnikova L, Fouchier RA, Berger A, Burguiere AM, Cinatl J, Eickmann M, Escriou N, Grywna K, Kramme S, Manuguerra JC, Muller S, Rickerts V, Sturmer M, Vieth S, Klenk HD, Osterhaus AD, Schmitz H, Doerr HW: Identification of a novel coronavirus in patients with severe acute respiratory syndrome. N Engl J Med 2003, 348: I967-1976. 
9. Ksiazek TG, Erdman D, Goldsmith CS, Zaki SR, Peret T, Emery S, Tong S, Urbani C, Comer JA, Lim W, Rollin PE, Dowell SF, Ling AE, Humphrey CD, Shieh WJ, Guarner J, Paddock CD, Rota P, Fields B, DeRisi J, Yang JY, Cox N, Hughes JM, LeDuc JW, Bellini WJ, Anderson LJ, SARS Working Group: A novel coronavirus associated with severe acute respiratory syndrome. N Engl J Med 2003, 348: 1953-1966.

10. Peiris JS, Lai ST, Poon LL, Guan Y, Yam LY, Lim W, Nicholls J, Yee WK, Yan WW, Cheung MT, Cheng VC, Chan KH, Tsang DN, Yung $\mathrm{RW}, \mathrm{Ng} \mathrm{TK}$, Yuen $\mathrm{KY}$ : Coronavirus as a possible cause of severe acute respiratory syndrome. Lancet 2003, 36I: $1319-1325$.

II. Marra MA, Jones SJM, Astell CR, Holt RA, Brooks-Wilson A, Butterfield YSN, Khattra J, Asano JK, Barber SA, Chan SY, Cloutier A, Coughlin SM, Freeman D, Girn N, Griffith OL, Leach SR, Mayo M, McDonald H, Montgomery SB, Pandoh PK, Petrescu AS, Robertson G, Schein JE, Siddiqui A, Smailus DE, Stott JM, Yang GS, Plummer F, Andonov A, Artsob H, Bastien N, Bernard K, Booth TF, Bowness D, Czub M, Drebot M, Fernando L, Flick R, Garbutt M, Gray M, Grolla A, Jones S, Feldmann H, Meyers A, Kabani A, Li Y, Normand S, Stroher U, Tipples GA, Tyler S, Vogrig R, Ward D, Watson B, Brunham RC, Krajden M, Petric M, Skowronski D, Upton C, Roper R: The Genome sequence of the SARS-associated coronavirus. Science 2003, 300:1399-1404.

12. Rota PA, Oberste MS, Monroe SS, Nix WA, Campagnoli R, Icenogle JP, Penaranda S, Bankamp B, Maher K, Chen MH, Tong S, Tamin A, Lowe L, Frace M, Derisi JL, Chen Q, Wang D, Erdman DD, Peret TCT, Burns C, Ksiazek TG, Rollin PE, Sanchez A, Liffick S, Holloway B, Limor J, McCaustland K, Olsen-Rasmussen M, Fouchier R, Gunther S, Osterhaus ADME, Drosten C, Pallansch MA, Anderson LJ, Bellini W]: Characterization of a novel coronavirus associated with severe acute respiratory syndrome. Science 2003, 300:1394-1399.

13. Snijder EJ, Bredenbeek PJ, Dobbe JC, Thiel V, Ziebuhr J, Poon LLM, Guan Y, Rozanov M, Spaan WJM, Gorbalenya AE: Unique and conserved features of genome and proteome of SARS-coronavirus, an early split-off from the coronavirus group 2 lineage. J Mol Biol 2003, 331:991-1004.

14. Gorbalenya AE, Snijder EJ, Spaan WJ: Severe acute respiratory syndrome coronavirus phylogeny: toward consensus. J Virol 2004, 78:7863-7866.

15. van der Hoek L, Pyrc K, Jebbink MF, Vermeulen-Oost W, Berkhout RJ, Wolthers KC, Wertheim-van Dillen PM, Kaandorp J, Spaargaren J, Berkhout B: Identification of a new human coronavirus. Nat Med 2004, 10:368-373.

16. Fouchier RA, Hartwig NG, Bestebroer TM, Niemeyer B, de Jong JC, Simon $\mathrm{H}$, Osterhaus $\mathrm{AD}$ : A previously undescribed coronavirus associated with respiratory disease in humans. Proc Natl Acad Sci U S A 2004, 101:6212-6216.

17. Vabret A, Mouthon F, Mourez T, Gouarin S, Petitjean J, Freymuth F: Direct diagnosis of human respiratory coronaviruses 229E and $0 C 43$ by the polymerase chain reaction. J Virol Methods 200I, 97:59-66.

18. Stephensen CB, Casebolt DB, Gangopadhyay NN: Phylogenetic analysis of a highly conserved region of the polymerase gene from II coronaviruses and development of a consensus polymerase chain reaction assay. Virus Res 1999, 60:18I-189.

19. Glezen WP, Greenberg SB, Atmar RL, Piedra PA, Couch RB: Impact of respiratory infections on persons with chronic underlying conditions. JAMA 2000, 283:499-505.

20. Mclntosh K, Chao RK, Krause HE, Wasil R, Mocega HE, Mufson MA: Coronavirus infection in acute lower respiratory tract disease in infants. J Infect Dis 1974, 130:502-507.

21. Gagneur A, Sizun J, Vallet S, Legr MC, Picard B, Talbot PJ: Coronavirus-related nosocomial viral respiratory infections in a neonatal and paediatric intensive care unit: a prospective study. J Hosp Infect 2002, 51:59-64.

22. Vabret A, Mourez T, Gouarin S, Petitjean J, Freymuth F: An outbreak of coronavirus OC43 respiratory infection in Normandy, France. Clin Infect Dis 2003, 36:985-989.

23. Pene F, Merlat A, Vabret A, Rozenberg F, Buzyn A, Dreyfus F, Cariou $A$, Freymuth F, Lebon P: Coronavirus 229E-related pneumonia in immunocompromised patients. Clin Infect Dis 2003, 37:929-932
24. Hendley JO, Fishburne HB, Gwaltney JM Jr: Coronavirus infections in working adults. Eight-year study with $229 \mathrm{E}$ and OC43. Am Rev Respir Dis 1972, 105:805-8II.

25. Sun ZF, Meng XJ: Antigenic cross-reactivity between the nucleocapsid protein of severe acute respiratory syndrome (SARS) coronavirus and polyclonal antisera of antigenic group I animal coronaviruses: implication for SARS diagnosis. J Clin Microbiol 2004, 42:235I-2352.

26. Thompson JD, Gibson T], Plewniak F, Jeanmougin F, Higgins DG: The CLUSTAL_ $X$ windows interface: flexible strategies for multiple sequence alignment aided by quality analysis tools. Nucleic Acids Res 1997, 25:4876-4882.

27. Nicholas KB, Nicholas HB, Deerfield DW: GeneDoc: analysis and visualization of genetic variation. Embnet News 1997, 4:14.

28. Kumar S, Tamura K, Jakobsen IB, Nei M: MEGA 2: molecular evolutionary genetics analysis software. Bioinformatics 200I, 17:1244-1245.

\section{Pre-publication history}

The pre-publication history for this paper can be accessed here:

http://www.biomedcentral.com/1471-2334/5/6/prepub
Publish with Biomed Central and every scientist can read your work free of charge

"BioMed Central will be the most significant development for disseminating the results of biomedical research in our lifetime. " Sir Paul Nurse, Cancer Research UK

Your research papers will be:

- available free of charge to the entire biomedical community

- peer reviewed and published immediately upon acceptance

- cited in PubMed and archived on PubMed Central

- yours - you keep the copyright 